\title{
On Higher Education
}

Transformation

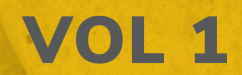

\section{SCHOLARLY \\ ENGAGEMENT AND \\ DECOLONISATION}

Editors:

M Crul, L Dick, H Ghorashi \& A Valenzuela Jr

Views from South Africa,

The Netherlands and the United States 


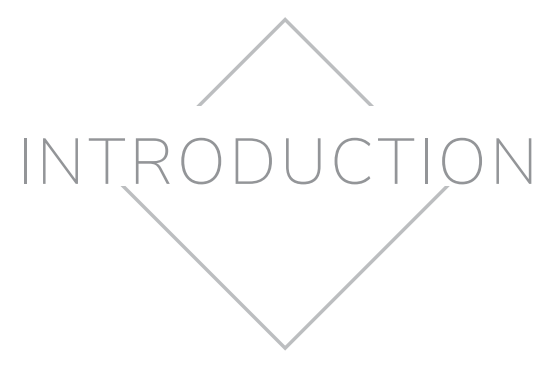

\section{Scholarly engagement and decolonisation}

\section{Views from South Africa, The Netherlands, and the United States}

Maurice Crul, Liezl Dick, Halleh Ghorashi \&s Abel Valenzuela Jr

Influential sociologists define late modernity as having two significant conditions which distinguish it from early modernity. The first is that of extreme individuality resulting from the modern person's struggle for autonomy against solid categories (e.g. tradition, culture, religion) which once constrained choices and action. The second condition concerns the changing nature of power and domination from visibly coercive forces to invisible ones.

Extreme individuality results from the struggle for autonomy that has decreased the relational capacity of individuals. In Bauman's (2000) words, this has led to a slow disintegration of citizenship, with the consequence being that the 'public' has become colonised by the 'private'. Colonising the public is manifested through the dominance of private needs and frustrations in the public space and emptying that space of collective issues. There is a need for a more balanced and reflective connection between autonomy and social connectivity in order to restore the lost relational capacity of late modern individuals. This involves interplay between the ideal of self-realisation and altruistic commitment to the public good. 


\section{SCHOLARLY ENGAGEMENT AND DECOLONISATION}

The second condition concerns the way power manifests itself. In the current era, it is not so much the visible and coercive forms of domination or suppression that are at play, but rather normalised structures and discourses of exclusion. These normalised structures have the greatest impact when processes of othering lead to conditions of durable inequality. An example of normalised power is when negative images of minorities are taken-forgranted in everyday interactions. Coercive power, on the other hand, is more visibly forceful. Iris $\mathrm{M}$. Young refers to the normalisation power of othering as hegemonic norms constituting gender, racial and cultural hierarchies of difference which reproduce structures of inequality and exclusion in everyday practices (Young, 2007). In these normalised practices members of non-privileged groups are depicted as both absolutely different and "morally inferior" (Young, 2007:104). It is particularly the taken-for-granted nature of power that severely limits the possibilities of resistance. This necessitates the revitalisation of the concept of democracy as giving rise to public inclusive spaces that are particularly sensitive to structures and practices of injustice (Young, 2002).

\section{CONSEQUENCE: NORMALISED DISTANCE/EXCLUSION}

When the existing process of othering develops into increased distance and even hatred between groups, mutual estrangement becomes normalised, strengthening the urge to stay in one's comfort zone and keep it pure from the intrusion of others. Often unintentionally shaped, these purified and homogenised societal zones create conditions for an increased sense of uneasiness about diversity, and may even become a threat to it. This process has various impacts on societal interactions. First, individuals who are socialised in homogenised environments develop language clumsiness in their interactions with individuals from other backgrounds. This stems from the lack of opportunities to develop language sensitivity through practice in diverse environments. At a deeper level, this cultural and social distance results in feelings of strong relational disidentification, instead of learning to identify with others in a range of spaces shared with people from different backgrounds.

Thirdly, if these feelings of uneasiness and fear are not countered, they can lead to mistrust and envy of others, which in turn can result in various forms of conflict: (1) struggle for rights to distributed resources (hierarchies of 
access), or (2) claims regarding who has the right to belong in certain places (hierarchies of belonging). Although the process of othering is quite visible in a public space, the nature of the power structures reproducing them is not always as visible. The dominant discourses informing these images of the self and the other, reproduced in the processes of daily interaction - including the colonial cultural archive (Wekker, 2016) - are not imposed on individuals or groups through coercive power. Instead, they are normalised because they are taken-for-granted. Thus, the major problem that societies are facing now is that "they stopped questioning themselves" (Bauman, 2000:22).

We need to start questioning the power structures that are reproducing othering and homogenised zones of disconnectedness in order to unsettle the normalised discourse. We need spaces, conditions, and practices that disturb normalised exclusionary structures. People need societal spaces that connect individuals to the issues of living together as part of a heterogeneous society. The increase in estrangement that is exacerbated by homogenised zones empties the public sphere of societal sensitivities that are essential for connecting individuals in increasingly diverse and polarised societies. By reflecting on and questioning the taken-for-granted foundation of these zones, space is created for imagining sustainable societal engagements that unsettle the underpinning of comfort zones. The feeling of comfort in homogenised zones will fade when the distance they cause results in long-term societal conflicts. The alternative is to create unsettling spaces of connection that are open and reflective enough to enable creative and heterogeneous alliances. As Beck and Beck (2002) put it, we need the "invention of the political," or to create societally engaged, vibrant and dynamic zones that connect reflexivity to acts of inclusion.

\section{THE ROLE OF ACADEMIA}

Considering that the core task of academia is to provide social critique and reflection, universities have an undeniable role in the quest for increased inclusiveness and resilience in relation to the normalised structures of exclusion. The social sciences and humanities in particular could play an essential role in enlarging societal imagination or, in Mills's words, "the sociological imagination" by connecting everyday personal realities with larger social realities (Mills, 2000:15). This means engaging with the narratives 


\section{SCHOLARLY ENGAGEMENT AND DECOLONISATION}

of uneasiness, indifference and exclusion by connecting them to historical and societal contexts. One can go beyond the social sciences and argue that the task of academia is to improve the human condition (Arendt, 1958), and to create conditions for developing meaningful, reflective spaces that bring the past and present together, and in so doing move beyond hasty and thoughtless actions in order to enable a sustainable future. Bauman (2000) argued for academia to come as close as possible to yet hidden human possibilities by questioning obvious and self-evident assumptions. In this process, it is essential to consider individuals as complicit in the process of reproducing the exclusive, yet hidden, power structures in different settings they are part of, even with the best intentions. The hidden, taken-for-granted power of discourse means that the ways in which individuals are complicit in certain discursive spaces is often normalised. This means that without reflexivity, positive inclusionary intentions do not always lead to imagined acts of inclusion. This realisation is quite crucial for academic institutions. In principle, their intention is to be inclusive learning environments for all talents regardless of race, ethnicity or gender. The reality, however, is that academicinstitutions can become complicit in reproducing the normalised power, manifesting in the best opportunities and the best positions in academia going to those from privileged groups.

As institutions of higher learning continue to adjust to changing demographics and other social processes, universities will undergo changes and push new research agendas, including programmes and policies on diversity and inclusivity. These changes and processes involve adjusting pedagogical and curriculum norms, providing guidance and training, as well as exploring and instituting best practices on teaching diversity and being sensitive. It will, however, also be about power sharing and leadership by the yet mostly male and 'white' educators, managerial staff, and especially administrative leadership. This is a huge effort, and this transformation is probably one of the greatest challenges universities have experienced in their histories. Crul, one of the editors of this volume, has developed a four phase diversity transformation model for institutions of higher learning that describes the processes and phases that universities go through sequentially (Crul \& Lelie, 2020) as they grapple with how to implement programmes of diversity and inclusivity. He distinguishes between the (a) awareness phase, (b) the deficit phase, (c) the critical race and diversity mobilisation phase and finally, (d) the institutional phase. 


\section{INTRODUCTION Scholarly engagement and decolonisation}

Each phase comes with its own struggles and conflicts while moving forward the process of transformation, or sometimes even forcefully taking small steps back in the process. These four stages can slow down or move into stages or periods of stagnation in which the institution, after significant or even strategic investments, fall short in terms of moving the entire institution forward. Instead of moving an entire institution, campus leaders decide to instead invest in smaller or discrete components of an institution such as student services, or a special minority or diversity programme that might be housed in the letters and social sciences division where matters of diversity and inclusivity are often relegated or deemed easier to implement.

The contributions in this volume speak to different aspects of a university's transformation and its engagement with pedagogies and research focused on matters of diversity. The transformations relating to student and staff interactions, the positionality of academics of colour from immigrant backgrounds and 'white' academics, challenging the existing curriculum and policies, developing alternative teaching courses, innovative pedagogies and engaged research opportunities, as well as the transformation of the power structures in institutions of higher learning, are making differences in students' lives, their educational experience and the institutions and faculty/staff who participate in diversity and inclusive strategies.

\section{Awareness phase}

The rich and detailed description of universities' institutional and teaching practices are discussed in this volume, and shows that all of them have passed the first awareness phase by now, largely covering the period when institutions start to realise the presence of a new demographic, and the demand by students and others for culturally and contemporary relevant courses and research opportunities. These new demands are predicated on social networks, which are one of the main platforms for discussions centred on inclusivity and diversity and students increasingly clamouring for courses and research opportunities that give meaning to their own minority and immigrant experiences. As a result, universities increase their investments and attention on data gathering based on the ethnic and racial background of students, on staff, faculty, and administrators. This plays an important role in this phase as new university actors (students, including graduate students) assess their own place at the 


\section{SCHOLARLY ENGAGEMENT AND DECOLONISATION}

university and their research and learning contributions and participation on matters (topics) meaningful to them and their respective communities. Access and greater representation in the student body by minorities and immigrants is often the main topic addressed in this period.

\section{Deficit phase}

A deeper level of consciousness usually emerges from a state of newfound awareness among students and the faculty body as they engage with students and others on matters of equity and inclusion. Outside of the university, we see elected officials, community leaders, civic leaders and others increasingly vocalising their demands regarding lack of representation, or about a deficit in courses and research topics important and relevant to those (e.g. immigrants, minorities, the other) contesting and pushing back against a relatively homogenous university. Students, faculty, staff and administrators are often confronted with new challenges when new groups of students of colour matriculate-institutions are inadequately prepared or don't fully understand the unique, nuanced differences among students from new groups that aren't enrolled at the university. Questions of adequacy, preparedness and ability are often discussed in order to try to understand the skills, resources, deficits and assets needed to succeed. University officials are keen to understand the reasons for premature drop-outs during the firstyear. Some institutions launch programmes, collect data, engage with students and staff and create policies and programmes to better integrate and enhance student success. Policies in general are fixated at modelling the new students according to the traditional 'white' or middle- and upper-class student whose educational experience and opportunities vary widely.

As a result, in this second phase, a deficit approach is usually developed in which students with an immigrant or minority background are considered as lacking certain skills or competencies. The skill gap is addressed by developing extra courses or helping the students adapt to the university surroundings. To be certain, the evidence is mixed, but many of these so-called deficit policies fail to deliver or only close part of the gap. This often results in a 'crisis' of the institutional diversity policies and can potentially cause a backlash for the very students the policies were designed for. 


\section{Critical race and diversity mobilisation phase}

In this next phase, mostly through student, faculty, and staff mobilisation, new critical race and diversity perspectives are put on the agenda, including increased opportunities for research, teaching and service in this area. In this phase, institutional practices and policies become increasingly scrutinised. For instance, the way teaching is practiced, which curriculum is taught and how guidance and counselling is done to address issues of race, class, immigration background, religion and other statuses. Many of the chapters in this volume address these issues as they interplay and engage in different campus settings across three continents. During this phase, academic senate, councils and other governing bodies, including students, faculty and sometimes community members are installed to revise the curriculum based on an intercultural, decolonial or anti-racist social justice perspective. Depending on the leverage of the group that is pushing, these courses are adapted or new courses are developed. Similarly, university committees are established to address campus-wide issues, plan or discuss a campus matter or devise policies. Resources within minority and migrant students and staff groups (and sometimes faculty) within the universities are also often mobilised in this phase. Allies are developed with concerned faculty, administrators and other campus leaders who genuinely believe they have a stake in improving educational outcomes on their own campus.

At more forward thinking universities, diversity officers, often with a migrant, minority, or female background, are installed and a structure is developed to consult and include silenced voices. Setting up programmes that support ethnic minority student organisations and peer mentor projects from the same ethnic groups are often part of this effort too. In this phase, it is especially important to keep track of how widespread the reforms become, and if scale and efficacy is being reached. For example, if done in a piece-rate manner, reforms usually lack a clear impact; if part of a more comprehensive effort, important reforms can have a long lasting impact. An example of the first is when intercultural or critical race teaching training courses are voluntary, or when faculties can decide not to implement them as a requirement. In such a case, they only reach the people who are already convinced that new practices and policies need to be implemented. The autonomy of teaching and research faculties often make it difficult to implement these policies top-down. In this phase, forces who 


\section{SCHOLARLY ENGAGEMENT AND DECOLONISATION}

oppose the changes often also get mobilised and conflicts can erupt, which can involve both staff and students. These conflicts arise even when this phase mostly does not yet affect existing power structures. When students and faculty begin to impact administrative power structures, including alumni, donors and upper administration, conflict likely ensues and universities either march forward ever cautiously (sometimes taking a few steps back), or they enter into a status quo or stagnant state of being. Institutions of higher learner placate a growing minority, but vocal student body and a non-minority student body also view and feel the changing demographics and clamour for leadership, discussion, as well as inclusive environments that engage them as well.

\section{Institutional phase}

In the last phase, the institutional phase, the institution itself is the main object of change. In this phase the 'sharing of power' by 'white', mostly male educators, administrative leadership and managerial staff with 'black' ethnic minority or staff with a migrant origin are put on the agenda and decision-making, inclusion, and real engagement between different university/college actors takes place to make the institution accountable. This last stage is difficult to achieve and requires significant investments in resources, politics and political strategising, as well as the creation, passage, and adjustment of policies, the pushing back against normative cultural processes at the university and staying on the course of change. Once the ship has started to turn, it becomes difficult to reverse course, and reaching a stage of institutional change becomes reality. If this phase is effective and moving forward, it is usually accompanied by a push towards equity among teaching and managerial staff.

For this final phase to be effective, as some of the authors in this volume write, bottom-up power needs to be mobilised, recruiting policies need to be scrutinised and anti-discrimination policies should be firmly implemented. These changes must be signalled and then implemented from the higher, if not the highest level of the campus administration - from the Rector or Chancellor downwards. The three universities in this volume are, of course, in different phases and have to work in very different contexts. The four phases do not always follow each other perfectly, and sometimes a phase is skipped, or 
inertia or stagnation takes place. The pace at which universities work through these phases depends on the pressure put on the institution by students, their alumni, donor base, and on whether they are public or private institutions.

The speed at which the student population is changing also becomes a factor. Whether or not the changing student population is a business case also plays a role, particularly during up and down swings of the regional and country economy when unemployment leads to greater interest and matriculation at institutions of higher learning. As to be expected, the general political climate influences the process from outside and it can also very much impact from within.

The University of California, Los Angeles (UCLA) has the longest tradition of transforming the institution, and is taking importantsteps in the diversification of its faculty, staff and administrative management (not to mention the students who the campus prides as being one of the most socio-economically and racially diverse campuses in California, as well as the rest of the country). It is also deeply engaged in the classroom and in Los Angeles through its research, service activities and its support of engaging the local and encapsulating the surrounding region. For well over five decades, UCLA has invested significant resources in building ethnic studies departments and student services, including teaching and research departments (fully-fledged academic units) such as Chicana/o Studies, African American Studies, Asian American Studies and American Indian Studies programme. Almost simultaneously, the university also began investing in burgeoning programmes in Gender Studies, LGBTQ Studies, Labour and Workplace Studies and Civic Engagement. These programmes, which include faculty members, and the staff, have all produced an impressive array of leaders, change agents and others to advocate on behalf of the university, and to engage it with the campus body and Los Angeles.

To be certain, UCLA has been doing this for a long time, but it has only been in the past decade or so that the institutional changes that began 50 years ago, such as the development of ethnic studies, have now become institutionalised and their efficacy is more apparent than ever. As a result of UCLA's investment in this area, including time, space and resources, the Los Angeles campus of the University of California has contributed to an important alumni base from these communities, including powerful elected officials, private enterprise 


\section{SCHOLARLY ENGAGEMENT AND DECOLONISATION}

capitalists, prominent and successful athletes, and an academic reputation that recently ranked UCLA the number one ranked university in the globe. Indeed, former Chancellor of UCLA, Charles Young, once quoted during UCLA's rise, that UCLA's "greatness occurred simultaneously with its investment in ethnic studies and matters of diversity and inclusivity".

As UCLA enters a more mature period of institutionalisation, the campus is still confronting matters of diversity and inclusivity relating to representation, socio-economic diversity and race. UCLA used to boast of its socioeconomic diversity, which has now fallen and contributes to a less diverse campus in its class composition. In addition, the campus continues to struggle with matriculating a larger number of black students. Many find these numbers unacceptable given the concentration of African Americans in California and Los Angeles. Diversity in Latino/a and Asian admissions are robust and increasing annually though the university is constantly trying to do better. Appointments of senior administrative officers (from Vice-Chancellors and Deans to important campus posts) have made a difference in directing values and priorities to enhance student success - making UCLA even more diverse and inclusive. In many ways, the large ship that is UCLA began to turn in the direction of a more inclusive and diverse campus and as a result, moving backwards is increasingly more difficult, but still occurs on a few occasions.

The Vrije Universiteit Amsterdam (VU) was one of the first universities to formulate diversity policies among all the universities in The Netherlands. This has partly come about because of the history of the university in which emancipation of the protestant part of the population was already deeply embedded in the DNA of the organisation. The VU was founded with the explicit goal of making social mobility possible through education, also for those who come from families with little formal education. Because of its religious character and partly because of its location in Buitenveldert, Amsterdam, students with a Muslim background in Amsterdam felt more at home in the VU in Amsterdam than at the University of Amsterdam. The VU was also one of the first Universities that accommodated halal food in the canteen and offered space for praying. It has also had an active policy to support Islamic and Turkish student organisations for the past two decades already. 


\section{INTRODUCTION - Scholarly engagement and decolonisation}

Even when the VU was certainly ahead of the curve in its awareness of the changing student population in comparison to other universities with large groups of students with an immigrant background, most of the attention of the diversity policies developed within the first phase was aimed at the students with an immigrant background without necessarily making any changes to the organisation itself. This, however, doesn't mean that these activities have not had any effect. Especially in mobilising the student voice and helping firstgeneration students find their place in the university, these activities have been very important. For instance, first-generation students who have followed the summer school programme often became active students in the organisation of the university.

Only in the last five years, the focus has started to shift towards looking at how the organisation should adapt given that now a third of the students studying for a Bachelor's degree are of immigrant descent. A number of interventions have been targeting both teaching staff and the curriculum. One of the problems in implementing these interventions has been that most of it has been on a voluntary basis. Both the participation in intercultural training and the adaptation of curriculum have been bottom activities, mostly mobilising people that are already convinced that structural changes are necessary.

The biggest challenge for the Vrije Universiteit (VU) is now still ahead by making the organisation more inclusive and the staff more diverse. In 2018, the first inventarisation took place about the ethnic composition of the staff by means of a staff survey. It showed that the VU has a considerable amount of international staff as you would expect from a prestigious university in Amsterdam. However, the Dutch immigrant student population, which makes up about a quarter of the students, is hardly represented among the staff. Among the PhD students and junior teachers, we see the first talents entering the staff, but it will take a much bigger effort to enhance their presence in the staff as a whole. The staff figures, in combination with the student figures and the outcomes of the student survey, which looked at belonging and student success, will be the starting point for the debate in the faculties to make the organisation more inclusive.

The VU had an important link to the Afrikaner Protestant Universities in South Africa. This strong collaboration and identification was ongoing well into the period of apartheid. While many organisations in The Netherlands 


\section{SCHOLARLY ENGAGEMENT AND DECOLONISATION}

asking for a boycott, the VU was very late in joining these forces and supported the Afrikaner universities morally and through exchange for a long time. This is a stain on the history of the University which has not yet been fully recognised or researched. It is not only about making a formal apology for supporting apartheid's institutions in that era, but also about understanding why the VU identified with the policies of the white Afrikaner population in South Africa for so long at the expense of the black population. The lessons to be drawn from this collaboration should guide the future in the debates about racism, decolonisation and diversity.

When South Africa became a democracy in 1994, the University of the Free State (UFS), as a historically white university (established in 1904), had to implement various change initiatives and policies to ensure broader access to a diverse student corps who only very selectively had access to tertiary education under apartheid. Black students were allowed to register, and English was adopted (alongside Afrikaans) as a language of instruction. The demographics of the university's students changed drastically - it was reflected in the on-campus student accommodation spaces (Githaiga et al., 2018:774). The increased diversity resulted in racial clashes between students, especially those residing in on-campus residences. Several attempts that were made to integrate black and white students were met with severe resistance and violence.

The height of resistance to racial integration and transformation, which also 'exposed' the deficit phase of the UFS's transformation process, was the so-called 'Reitz-incident'. Early in 2008 a video surfaced on YouTube where four white male on-campus residence students filmed a video featuring the humiliation of five black cleaning staffing in a hazing ritual to protest against the racial integration of residences (Marais \& De Wet, 2009; Lazenby \& Radebe, 2011). This incident served as an opportunity for UFS to intensify and fine-tune transformation initiatives, and institutional transformation became a priority. The first black Vice-Chancellor was appointed shortly after, and transformation and integration practices and policies were scrutinised. Over the years the demographics of UFS changed and black students became a majority. This resulted in an increased demand for institutional transformation. The impact of \#RhodesMustFall in 2015 on tertiary institutions in South Africa, and concomitant calls for decolonisation, cannot be underestimated. 


\section{INTRODUCTION - Scholarly engagement and decolonisation}

The \#FeesMustFall movements of 2015 and 2016 also mobilised students, and demands for "free, decolonised higher education", as well as broader access and inclusivity, were taken seriously by the ANC government.

The UFS accepted a new language policy in March 2016, replacing English and Afrikaans parallel medium with only English as the primary medium of instruction. In December 2017, the Constitutional Court of South Africa ruled that the UFS can continue with the implementation of the policy, which was ruled lawful and in line with the constitution after civil rights group Afriforum appealed to the ruling of the Supreme Court of Appeal, who also ruled in favour of the policy. Executive management welcomed the ruling of the Constitutional Court, stating that the parallel medium policy had the unintentional consequence of segregating white Afrikaans students and black students who preferred to study in English. With the changing of the language policy, a UFS executive management wanted to create an academic environment where language could not be used as a mode of exclusion.

In November 2018, the UFS council approved the removal of the MT Steyn statue, a former Free State Republic president, from its location in front of the university's main building. This was the result of a task team who investigated symbolic representations on campus, and how this hindered social inclusion in the diverse UFS campus community. Executive management made this decision after a long consultation process during which a broad spectrum of stakeholders, students, alumni and staff were consulted. It became evidently clear that the majority of the UFS student body felt unwelcome with the presence of symbolic representations dating from the apartheid era since it is representative of a history that they feel excluded from, according to Prof Francis Petersen, Rector and Vice-Chancellor of UFS.

Needless to say, transformation is an ongoing process at UFS. The conversation about the decolonisation of the curriculum is ongoing, and institutional transformation and inclusivity are prioritised. The challenges are rife, but executive management, staff and students seemed to have learned not to waste a 'good crisis', which can serve as guidance not only to address the blind spots of all stakeholders, but also highlight and address the lack of political and empathic will in the process of institutional transformation. 


\section{SCHOLARLY ENGAGEMENT AND DECOLONISATION}

In the different sections of the book, various authors from different parts of the globe (mainly South Africa, the United States and The Netherlands) discuss the theoretical, methodological and empirical possibilities of creating inclusive institutions, enabling practices to include marginalised voices and identities, and generating alternative spaces for engagement, participatory research and knowledge creation.

\section{THEME I - INSTITUTIONAL INCLUSIONARY INITIATIVES}

Karen van der Zee and Brendy Boogaard address the importance of the organisational 'readiness' of universities in successfully incorporating diversity among staff members and students in their chapter, 'Assessing the readiness of universities for diversity: Application of a diversity scan'. Universities are increasingly concerned with embracing diversity within their institutions, either as an active strategy driven by their aspired contribution to multicultural societies or simply as a response to an increasing number of students of minority background enrolling in their programmes. The authors argue that successful diversity policies aimed at student populations cannot exist without diversity among faculty and staff, who act as role models and contribute to the understanding of the educational needs of students from different backgrounds. In their chapter, Van der Zee and Boogaard describe the diversity scan as an instrument that diagnoses the 'readiness' of the organisational context of universities for effectively incorporating diversity among their employees. The instrument results in concrete recommendations for increasing an organisation's readiness for diversity. The authors illustrate the impact of the scan on the case study of its application at the VU.

Cindy Fan critically interrogates the gender inequity in higher education spaces, with a specific focus on senior-level positions in her chapter, 'Gender inequity in American higher education'. She argues that the conventional explanation for the lack of women in senior academic leadership positions in the United States does not hold. The 'pipeline myth' claims that too few women are qualified for senior positions. Data for American higher education, however, refutes the 'pipeline myth', by showing that women have earned the majority of degrees at all levels, including doctoral degrees. Fan demonstrates that gender inequity in higher education is due to the intangible systemic 


\section{INTRODUCTION - Scholarly engagement and decolonisation}

barriers that prevent women from obtaining senior-level positions. Barriers to ascent to leadership roles are exacerbated for women of colour. In addition, the gender pay gap in academia persists. The persistence of gender glass ceilings in American higher education, shown to be prevalent across disciplines, is especially worrying when other public entities have a better representation of women overall. Fan avers that gender inequity in higher education needs to be more effectively addressed; academic institutions must identify and commit to clear action steps, such as fair and equitable hiring and promotion policies, search strategies that promote diversity, and institutional investment in identifying and supporting women and women of colour to become senior academic leaders.

\section{THEME II - DISRUPTING INSTITUTIONAL POWER/ MICROAGGRESSION}

In theme 2 of the book, the authors of all three chapters address their positionality as either black or white scholars or teachers working on issues of decoloniality, diversity and academia. Shirley Anne Tate, in her chapter 'On 'brick' walls and other Black decolonial feminist dilemmas', delves into the issue of anger and racial diversity in universities. Tate describes how, from her personal experience and other black scholars working in a predominantly white institution, these institutions are diversity averse in practice while claiming to be diversity sensitive. This creates a toxic climate for black and minority scholars working in these environments. The impact of racism on black women faculty creates anger through which white supremacy constructs them as 'angry black women'. Tate redefines the anger both scientifically and politically as institutional pain and regards the anger as productive because it is rooted in experiences of and responses to racialised gender injustice. She argues that this reconstruction is essential in the anti-racist social justice transformation of universities.

The chapter by Frans Kamsteeg, Ida Sabelis and HarryWels, 'Auto-ethnographic reflections on whiteness', sets out to rethink diversity in Dutch-South African higher education research. Their starting point is their own biographies. In this case, white male or female positionality in which gender in the case of the two male authors and their colour offers certain privileges. The chapter is 


\section{SCHOLARLY ENGAGEMENT AND DECOLONISATION}

written in the context of South Africa in which all three authors are engaged in academic work while being employed by a university in The Netherlands (Vrije Universiteit of Amsterdam). Where Tate discusses the perspective of the black academic, this chapter talks about the perspective of the white academic. It discusses being or becoming aware of the black pain while South Africa was changing from an apartheid state to becoming a post-apartheid state. How did this transformation impact their own transformation as scholars, their academic contacts and the power positions they hold or exercise in the South African academic world? In this positionality, a feminist and an anti-apartheid activist's perspective have shaped experiences and choices differently.

In Chapter 5, 'Disruptive moments and normative professionalism', the authors Ina ter Avest and Cok Bakker explore the (im)possibilities of a provocative pedagogy to stimulate the development of normative professionalism. They describe a technique used in two case studies to teach student-teachers awareness around their own religious or humanistic identity and positionality formed amidst a diversity of religious and secular worldviews. Making use of the Dialogical Self Theory and the instrument of self-confrontation, teachers' reflections on crises (so-called 'disruptive moments') are used to build personal identity capital while stimulating the development of teachers' professional development. The dialogical approach invites participants to reconsider their own positions and work on the construction of a so-called third position, doing justice to and recognising each participant's contribution in the process.

\section{THEME III - INCLUDING SILENT VOICES}

Gadamer defined bildung as "trained receptivity towards the otherness" (Gadamer in Abma, 2016:58). Although this concept of bildung is somewhat contested, this approach of the concept offers the possibility to think about the inclusionary spaces needed in academia to include unprivileged voices and identities (of students or colleagues) in academic institutions. This challenge has become even more salient because neoliberal structures of individualised successes and the language of excellence, have led to a decrease of time and space for reflective encounters and thoughtful contemplations. However, when the sources of exclusion work through normalised and repetitive practices of everyday interactions, the primary way to resist is to create delayed spaces for reflection. The act of delay as a first step, protects individuals 


\section{INTRODUCTION Scholarly engagement and decolonisation}

from what Thomas Eriksen (2001) called "the tyranny of the moment". "To go fast means also to forget fast," as Lyotard argued (in Janssens \& Steyaert, 2001:109). The hastiness of actions of late modern individuals strengthens the power of normalisation. Stopping to think and creating delayed in-between spaces of reflection inside hurried routines enables the academic community to rethink their position in these processes and, from time to time, to think of actions that can disrupt taken-for-granted structures within academia. Delayed interspaces of engagement help to include difference, yet go beyond dichotomies of difference (Ghorashi \& Ponzoni, 2014; Ghorashi \& Sabelis, 2013). The main challenge here is to rethink the normalised notion of otherness, which is reified as the opposite of the self or as a failure of sameness, and begin thinking of it as a dynamic and multiple state of becoming.

Several authors of this section convincingly demonstrate both the existence of exclusionary conditions in academia, and the strength of alternative education programmes, teaching praxis and methodologies to counter these structures and practices of exclusion.

In her chapter, 'Decolonising Research Methods', Nadira Omarjee discusses the importance of how alternative methodologies in which there is more room for engagement between participants of the research and the researchers as agents of co-producing knowledge challenge the conventional methods. In what she calls Agentic Reflexive Methodology (ARM), the power relation between the researcher and the research participant is levelled by developing a shared understanding in knowledge production through conversation. In this process, the integrity of the voices of the participants takes centre stage. This decolonising research methodology through conversation is reflexive, intersubjective, inclusive and transparent and relies on Freire's (1970) understanding of the pedagogy of the oppressed, by giving the voice to a previously marginalised group.

Hannah Leyerzapf, Hajar Rifi and Petra Verdonk show the exclusionary experiences of female Muslim medical students who are considered as ultimate others within medical education. Using the intersectional lens, they show that othering practices at the intersection of gender/religion/race highlight the gendered racialisation of medical education as an exclusive white space (Essed, 2005). The authors argue that (white) researchers studying diversity 


\section{SCHOLARLY ENGAGEMENT AND DECOLONISATION}

issues in (Dutch) academic medicine need to engage in critically reflexive dialogue on their own role in the research and on how research concepts such as 'cultural diversity' and 'migrant background' may be depoliticised and racialised terms with a link to white innocence and the silencing of antiracism perspectives in society and academia (Ahmed, 2012; Leyerzapf et al., 2018; Wekker, 2016).

The last two chapters of this section happen to be in conversation with each another. Charles Alexander, Jonathan Davis and Jonli Tunstall's chapter, 'Silenced voices', explores the achievements and the importance of Summer Bridge Programs at UCLA. The chapter from Gusta Linde Tavecchio and Leila Moayeri Pazargadi compares different Summer Bridge Programs and analyses them through the lens of critical perspective. Alexander shows the importance of the role of higher education practitioners, policy makers and educators at universities in supporting students from underserved and historically underrepresented backgrounds. He claims that UCLA's achievements in this domain occupy "an important space in said history". Tavecchio \& Pazargadi's chapter goes one step further and discusses the necessity of a combination of inclusive institutional support, critical pedagogical strategies and narrative didactics to give students with non-dominant backgrounds the alternative voice and identity capital needed to be resilient in normalised exclusionary structures such as academia.

\section{THEME IV - (ALTERNATIVE) SPACES FOR ENGAGEMENT}

The four chapters in this section describe and assess alternative spaces for community and university engagement. As campuses begin to engage students with research that is culturally engaging and relevant, faculty and students are increasingly drawn to exchanges, experiments and research engagements within and outside of their institutions of higher learning. These exchanges can be difficult and fraught with nuanced processes of conflict, exploration and engagement over issues of race, class, religion and the other. Students and faculty, sometimes for the first time, experience aggressions, difficult conversations, and at the same time, become enlightened and informed about the other. The contexts for these engagements are each unique and we caution that they should assessed for their case study and local context and 
specificity as opposed to broader generalities. The lessons from these chapters are gleaned most useful by assessing and applying their value piecemeal, in a local context, but with some reflection to apply elsewhere.

Beginning with Peer Smets, Baukje Reitsma and Halleh Ghorashi's chapter, the co-authors delineate the role of power in student engagement outside of the university, in a disadvantaged neighbourhood in Amsterdam. The chapter presents a very interesting case study of placing (housing) students in housing corporations in Amsterdam (VoorUit) in exchange for ten hours of local engagement with neighbourhood residents. The idea is to assist newcomers, with students acting as mediators and residents, to integrate into neighbourhood and city living environments. They find that this unique programme of integration by mixing (living together) VU students and local residents who come from disadvantaged backgrounds is mostly a process of mutual learning; of giving, taking, learning and sharing in a circular way. The chapter provides an excellent review of engaged scholarship and research and it provides a rich description of the interactions and experiences that the students undertook with their assigned families. We learn that positive benefits are realised for the neighborhood, the residents and the student participants.

Chapter 11 by Angelo Mockie and Marguerite Müller, as the title suggests, provides a unique portrait of social justice through arts and auto-ethnography. 'Portraits of social justice' draws on the powerful auto-ethnography method to explore issues of space, diversity and engaged scholarship. The authors explore the strong relationship between art and knowledge in a South African higher education context. The authors' chapter is targeted toward a more critical landscape of art and learning with the aim of working toward critical and socially just practices. To be certain, their project is an abject criticism of colonial education and their theoretical understanding of how higher education through art is transformational and decolonising. The chapter weaves through a performance (it is primarily a performative piece), exploring the complex and nuanced journey of art and auto-ethnographic narratives and art-based pedagogies. We learn that art and autobiographical processes of university exploration can profoundly shape where we work and how we interact in a university setting. 


\section{SCHOLARLY ENGAGEMENT AND DECOLONISATION}

In Chapter 12, Frans Kruger uses a student experience and mapping tool to explore knowledge acquisition by critically analysing campus spaces and their epistological and decolonial meaning. He describes a campus exercise where students were asked to walk, discuss and produce a campus map of spaces and what these spaces mean to them in terms of the university's entanglement with practices of coloniality or decoloniality. The author's exploration of space, campus walks, place, pedagogy and knowledge acquisition are unique and excellent processes from which to explore students' knowledge acquisition and their interpretation of a group walking and talking pedagogy as a decolonial practice from which to begin the transformation of campus spaces in order to become more inclusive, diverse and relevant to the campus and student body.

Chapter 13 by Isabel Coatlicue Durón explores the role of a community-based organisation focused on empowering secondary school students in Los Angeles and the organisation's affiliation with UCLA students, as well as those from other local universities as part of peer learning and engagement programme. The organisation's mission is to provide young people tutoring and other resources to obtain higher education, if they so choose. This organisation challenges both documented and undocumented young people to achieve their dreams and address their challenges through a college choice environment and consider how this is distinct from a 'college-going' environment. The author makes connections between directly supporting youth's understanding of the college-going process, and empowering experiences they reflect on that may serve as powerful motivators for persisting on a college track. The author argues that you need to consider not only how an organisation undertakes this work, but especially how it maintains this work over the long haul to impact multiple generations.

\section{CONCLUSION}

To conclude with a phrase from Bob Dylan, we could certainly say that "the times they are a-changin'”-for better and for worse. Looking at the increase in managerialism and marketisation in academia (Diefenbach, 2007) focusing on individualised excellence and increasing output demands (Bal et al., 2014), can make the future seem dim. Worldwide, including in welfare states such as The Netherlands, we observe that the reality of inclusion is far from being achieved, 
despite all the talk. Academia as a working environment still seems to be the natural habitat, or the comfort zone, of the privileged groups; despite growth in student diversity. Under the dominance of neoliberal policies, delayed spaces for reflection and meaningful conversations within academia (with and among colleagues and students) are shrinking because of the increased work pressure resulting from the often impossible task to meet expectations of performing excellently at all levels. In addition, it is useful to consider Merton's 'Matthew effect'. Once one receives a prize or a prestigious research grant, the rest will follow. As academics, there is a need to question these normalising structures that remove the breeding ground for playfulness, imagination and reflective engagement in academia. Without this breeding ground, we cannot serve our students and our societies as sources of inspiration to enlarge their imaginations (see also Ghorashi, 2016).

But our times are also changing for the better. Students all over the globe are protesting against these normalising and homogenising practices in academia and challenging universities about their societal role. Students in The Netherlands and, obviously, in South Africa have demanded the diversification of university personnel at all levels (including full professor positions) and have opposed Euro-centric and male-oriented teaching materials at colloquia. The most visible example in The Netherlands was the six-week sit-in by students and staff at the University of Amsterdam ${ }^{1}$ who were demanding more democracy and diversity at the university. These protests resulted not only in the university board stepping down, but also in the creation of several committees to look into the protestors' demands. One of these committees produced an important report on diversity under the supervision of the renowned critic of Dutch higher education, Prof Gloria Wekker. ${ }^{2}$ Another example is the petitioning by philosophy students at the VU for the diversification of philosophy by including in their curriculum more work from feminist and non-western philosophers. ${ }^{3}$ As a result of this action, an interdisciplinary minor in gender and diversity was developed at the VU and approved in December 2016.

\footnotetext{
1 http://bit.ly/30VE2ms [accessed 15 January 2016].

2 http://bit.ly/38XZn1g [accessed 2 March 2016].

3 http://bit.ly/38XZn1g [accessed 2 March 2016].
} 


\section{SCHOLARLY ENGAGEMENT AND DECOLONISATION}

In South Africa, the higher education landscape has been transformed by \#RhodesMustFall and \#FeesMustFall protest movements (Hendricks, 2018; Steyn Kotze, 2018). The \#fallist movements and the concomitant call for the decolonisation of the curriculum resulted in the destabilisation of a previous order, while a new order is yet to come. More people now have access to higher education than before, and challenging yet productive debates regarding decolonisation are taking place on campuses. The wider societal problems of South Africa, however, highlight the challenges students face after graduation. The unemployment rate of South Africa is currently $27,5 \%,{ }^{4}$ causing demotivation among students and graduates, while racism and racial tension, economic inequality, corruption and service delivery issues are indicators of the tumultuous political and economic landscape students find themselves in. The higher education sector in South Africa needs to critically reflect on transformation and its role in the broader society, as well as the role it should play in the future and wellbeing of citizens. Are universities in South Africa preparing their students sufficiently for the political and economic realities that await them after graduation? Do higher education institutions align their curriculums with the socio-economic and political issues of the day? The times they are indeed a-changin' in the higher education landscape in South Africa. An ongoing process of transformation should commit to the cultivation of heterogeneous spaces of inclusion where democratic values are upheld, challenging yet productive discourses can develop critical thinking skills, and where students, as a result, might learn what their predecessors struggled with fiercely; how to live with difference, value diversity and work toward a socially just society.

In the United States, some of the more noticeable changes include increasing calls for campuses to further diversify its student body, the faculty and, more recently, calls to diversify upper administrative positions where real power to transform the university or college exists. At UCLA, these positions include coveted Deanships and Vice-Chancellors, positions occupied by ladderranked (tenured) faculty who are plucked from their teaching positions and occupy positions that control resources for teaching units, faculty hires and financial aid. Access and cost of attending an elite institution of higher 
learning continues to drive many critics of higher education in the United States, including recent attacks on holistic admissions and affirmative action in the Ivy League, in which claims of unfairness towards certain immigrant or minority groups has the potential to pit different students against one another in the highly competitive cycle of admissions. In the particular case of Harvard University, a conservative group has filed a case claiming that Asian applicants are disadvantaged in their admissions when compared to other groups, including Latinos and African Americans potentially.

The issue is not so much gaining access to Harvard University, but rather gaining a larger piece of the total admission pie. At Harvard, Asian students represent about one quarter of the undergraduate student body. Shortly after the election of Donald Trump, some universities undertook a more proactive and engaged position to enhance student protections, particularly for undocumented students (at UCLA they number close to 1,000), Muslim identified students and international students, increasingly from Asia (China) and Iran. Many campus presidents signed pledges and moved to make their campuses safe havens or sanctuary spaces that would protect undocumented students in the case of ICE raids or massive deportation orders. Some of these efforts were led by various higher education constituents, including students and faculty and in some state legislatures, campuses (public) were legally mandated to make campuses safe for all students, including Muslim and undocumented students.

To coordinate some of these efforts, a national network of influential college and university presidents created the President's Alliance on Higher Education and Immigration to provide colleges with real time information on immigration policies, best practice efforts from different college campuses, and a network to push back, comment, and lobby against policies that harm campuses and make them less competitive internationally and go against their values of admitting and matriculating the best minds from anywhere in the world. Collectively, these efforts seem to be working in that the federal government has not targeted college campuses with the same vitriol and hate that they target at other institutions that enable and empower immigrants and their families. 


\section{SCHOLARLY ENGAGEMENT AND DECOLONISATION}

\section{REFERENCES}

Abma, T. 2016. Tragedy at the Modern University: An Advocacy for Bildung and Participatory Pedagogy. In:

M. Flikkema (ed.), Sense of Serving: Reconsidering the Role of Universities Now. Amsterdam: VU University Press, pp.50-61.

Ahmed S. 2012. On being included. Racism and diversity in institutional life. Durham: Duke University Press. https://doi.org/10.1215/9780822395324

Arendt, H. 1958. The Human Condition. Chicago: University of Chicago Press.

Bal, E.; Grassiani, E. \& Kirk, K. 2014. Neoliberal individualism in Dutch universities: Teaching and learning anthropology in an insecure environment. Learning and Teaching, 7(3):46-72. https://doi.org/10.3167/ latiss.2014.070303

Bauman, Z. 2000. Liquid Modernity. Cambridge: Polity Press.

Beck, U. \& Beck-Gernsheim, E. 2002. Losing the traditional, In: Beck \& Beck (eds.), Individualization. London: SAGE Publications. pp.1-22.

Crul, M. \& Lelie, F. 2020. Access to Higher Education and Retention of Students with a Migrant Background in The Netherlands: A Comparative Analysis. In: J. Bhabha, W. Giles \& F. Mahomed (eds.), A Better Future: The Role of Higher Education for Displaced and Marginalized People. Cambridge: Cambridge University Press.
Diefenbach, T. 2007. The managerialistic ideology of organisational change management. Journal of Organizational Change Management, 20(1):126-144. https://doi. org/10.1108/09534810710715324

Eijberts, M. 2013. Migrant women shout it out loud: The integration/participation strategies and sense of home of first-and second-generation women of Moroccan and Turkish descent. Amsterdam: VU University Press.

Eriksen, T.H. 2001. Tyranny of the Moment: Fast and Slow Time in the Information Age. London: Pluto Press.

Essed, P. 2005. Gendered preferences in racialized spaces: Cloning the physician. In: K. Murji \& J. Solomos (eds.), Racialization: Studies in Theory and Practice: Studies in Theory and Practice. Oxford: Oxford University Press. pp.227-247.

Ghorashi, H. 2016. The Times They Are a-Changin'. In: M. Flikkema (ed.), Sense of Serving: Reconsidering the Role of Universities Now. Amsterdam: VU University Press, pp.26-32.

Ghorashi, H. \& Ponzoni, E. 2014. Reviving agency: taking time and making space for rethinking diversity and inclusion. European Journal of Social Work, 17(2):161-174. https://doi.org/10.1080/136 91457.2013.777332

Ghorashi, H. \& Sabelis, I. 2013. Juggling difference and sameness: Rethinking strategies for diversity in organizations. Scandinavian Journal of Management, 29(1):78-86. https://doi.org/10.1016/j. scaman.2012.11.002 


\section{INTRODUCTION Scholarly Engagement and Decolonisation}

Githaiga, J.N.; Gobodo-Madikizela, P. \& Wahl, W.P. 2018. 'They dug up wounds': University of the Free State students' experiences of transformation and integration in campus residences. Race Ethnicity and Education, 21(6):773-790. https://doi.org/10.1080/13613324.2017.1 376633

Hendricks, C. 2018. Decolonising Universities in South Africa: Rigged Spaces? International Journal of African Renaissance Studies, 13(1):16-38. https:// doi.org/10.1080/18186874.2018.1474990

Janssens, M. \& Steyaert, C. 2001. Meerstemmigheid: Organiseren met verschil (Multivocality: Organising with a difference). Leuven: Universitaire Pers.

Lazenby, J.A.A. \& Radebe, K. 2011. Students' perceptions about institutional transformation at the University of the Free State. African Journal of Business Management, 5(14):5766-5774.

Leyerzapf, H.; Verdonk, P.; Ghorashi H. \& Abma T. 2018. "We are all so different that it is just ... normal." Normalization practices in an academic hospital in The Netherlands. Scandinavian Journal of Management, 34(2):141-150. https://doi.org/10.1016/j. scaman.2018.03.003
Marais, W. \& De Wet, J.C. (2009). The Reitz video: inviting outrage and/or pity? Communitas, 14:27-42.

Mills, C.W. 2000. The sociological imagination. New York: Oxford University Press.

Steyn Kotze, J. 2018. On Decolonisation and Revolution: A Kristevan Reading on the Hashtags Student Movements and Fallism. Politikon, 45(1):112-127. https:// doi.org/10.1080/02589346.2018.1418216

Young, I.M. 2002. Inclusion and Democracy. Oxford: Oxford University Press.

Young, I.M. 2007. Structural Injustice and the Politics of Difference. In: Justice, Governance, Cosmopolitanism, and the Politics of Difference: Reconfigurations in a Transnational World. Distinguished W.E.B. Du Bois Lectures 2004/2005. Berlin: Humboldt University, pp.79-116.

Wekker, G. 2016. White Innocence: Paradoxes of Colonialism and Race. Durham: Duke University Press. https://doi.org/10.1215/9780822374565 